Several N- and O-substituted derivatives of hydroxylamine, O-methylhydroxylamine, $\mathrm{N}$-trimethyl-hydroxylammonium iodide, phenylhydroxylamine, hydroxylurea and 6-hydroxylaminopurine, were tested for inhibitory activity against ADP-induced platelet aggregation. The results are summarized in Table I. None of the derivatives showed significant inhibitory activities except phenylhydroxylamine which showed the same potency as adenosine.

Inhibitory action of hydroxylamine against ADP-induced platelet aggregation was characteristic. Thus, the maximal aggregations were observed at about 1 minute after the addition of ADP and the deaggregations were observed thereafter (Fig. 1). The reasons for this deaggregation were not known. Similar observation has been reported with the inhibition by adenosine. . $^{\text {) }}$

Figure 2 showed that the inhibitory activity of hydroxylamine decreased the longer the interval of time between its addition to PRCP and the subsequent addition of ADP. The probable explanation for the loss of activity is that hydroxylamine was increasingly inactivated by some factors from platelets or plasma.

It has been proposed by Salzman, et al.9) that ATPase plays an important role in the platelet function. Recently, hydroxylamine has been shown to affect ATPases involved in active transport at cell membrane. ${ }^{10}$ Hence, the inhibitory activity of hydroxylamine against platelet aggregation might be related to the alterations of the enzyme function of platelets.

Acknowledgement The authors wish to express their sincere thanks to Mr. M. Ichino for his interests throughout the work.

9) E.W. Salzman, D.A. Chambers and L.L. Neri, Nature (London), 210, 167 (1966).

10) G. Sachs, M.M. Long, T. Tsuji and B.I. Hirschowitz, Biochim. Biophys. Acta., 233, 117 (1971).

\title{
Stereochemical Studies. XII.1) Effects of Neighboring Functional Groups on 1,2-Asymmetric Induction in the Reduction of Propiophenone Derivatives by Catalytic Hydrogenation
}

\author{
Kenji Koga, Yoshimitsu Yamamoto, and Shun-Ichi Yamada \\ Faculty of Pharmacentical Sciences, University of Tokyo
}

(Received September 21, 1971)

In preceding papers ${ }^{\mathbf{1}, \mathbf{3}}$ of this series, it has been reported that the stereochemical course of 1,2-asymmetric induction in the reduction of propiophenone derivatives with sodium borohydride depends on neighboring functional groups such as $-\mathrm{NH}_{2} \mathrm{HCl},-\mathrm{OH}$, and $-\mathrm{OCH}_{3}$, attached at $\alpha$ - and/or $\beta$-positions to the carbonyl group. Catalytic hydrogenation is a convenient general procedure for the reduction of carbonyl compounds to the corresponding alcohols. The present paper describes the effects of neighboring functional groups on the direction and the degree of 1,2-asymmetric induction in the reduction of propiophenone derivatives (I-IV) having a functional group at $\alpha$ - or $\beta$-position to the carbonyl group by

1) Part XI: K. Koga and S. Yamada, Chem. Pharm. Bull. (Tokyo), 20, 539 (1972).

2) Location: Hongo, Bunkyo-ku, Tokyo.

3) K. Koga and S. Yamada, Chem. Pharm. Bull. (Tokyo), 20, 526, 539 (1972). 


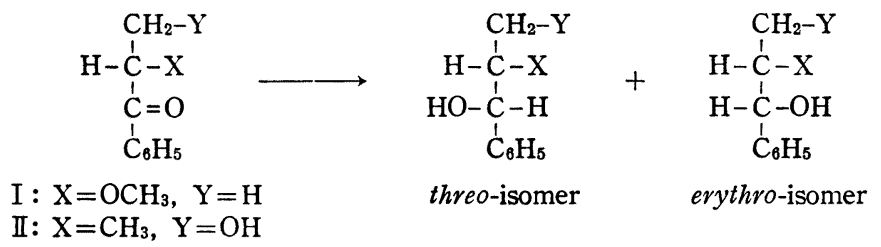

catalytic hydrogenation with $5 \%$ palladium on charcoal $(5 \% \mathrm{Pd}-\mathrm{C})$, platinum oxide $\left(\mathrm{PtO}_{2}\right)$, and Raney nickel W-2 (Raney Ni W-2). Determinations of the relative configurations of the diastereomers and methods for the analyses of their ratios in the reduction products have already been developed., ${ }^{\mathbf{1} 3)}$

TABLE I. Ratios of Diastereomers in the Catalytic Reduction of I and II

\begin{tabular}{|c|c|c|c|c|c|}
\hline \multirow[b]{2}{*}{ Compound } & \multirow[b]{2}{*}{$\mathrm{X}$} & \multirow[b]{2}{*}{$\mathrm{Y}$} & \multicolumn{2}{|c|}{ Reduction condition } & \multirow[b]{2}{*}{ erythro/threo } \\
\hline & & & $\begin{array}{l}\text { Catalyst } \\
\text { (Reagent) }\end{array}$ & Solvent & \\
\hline \multirow[t]{8}{*}{ I } & \multirow{8}{*}{$\mathrm{OCH}_{3}$} & \multirow[t]{8}{*}{$\mathrm{H}$} & \multirow{4}{*}{$5 \%$ Pd-C } & EtOH & $2.0-2.3$ \\
\hline & & & & $\mathrm{AcOH}$ & $2.0-2.2$ \\
\hline & & & & $\left.\mathrm{EtOH}-\mathrm{HCl}^{a}\right)$ & 1.4 \\
\hline & & & & $\left.\mathrm{EtOH}-\mathrm{NaOH}^{b}\right)$ & 8.1 \\
\hline & & & \multirow[t]{2}{*}{$\mathrm{PtO}_{2}$} & EtOH & $1.9^{c)}$ \\
\hline & & & & $\left.\mathrm{EtOH}-\mathrm{NaOH}{ }^{b}\right)$ & 9.0 \\
\hline & & & Raney $\mathrm{Ni}$ (W-2) & EtOH & 0.8 \\
\hline & & & $\mathrm{NaBH}_{4}$ & $\mathrm{EtOH}$ & $2.7-4.8^{d)}$ \\
\hline \multirow[t]{3}{*}{ II } & \multirow[t]{3}{*}{$\mathrm{OCH}_{3}$} & \multirow[t]{3}{*}{$\mathrm{OH}$} & $5 \% \mathrm{Pd}-\mathrm{C}$ & EtOH & $0.3-0.5$ \\
\hline & & & $\mathrm{PtO}_{2}$ & $\mathrm{EtOH}$ & 0.3 \\
\hline & & & $\mathrm{NaBH}_{4}$ & EtOH & $0.3-0.4^{d)}$ \\
\hline
\end{tabular}

a) 5 molar equivalents of $\mathrm{HCl}$ added; b) 5 molar equivalents of $\mathrm{NaOH}$ added; $c$ ) Some unknown products of low boiling points were also produced; $d$ ) Data taken from refrence 3.

Results of the reduction of 2-methoxypropiophenone (I) and 3-hydroxy-2-methylpropiophenone (II) are shown in Table I. Marked differences in stereoselectivity were observed in reduction of the ketone (I) under various conditions. The catalytic reduction of $\mathrm{I}$ with $5 \% \mathrm{Pd}-\mathrm{C}$ and $\mathrm{PtO}_{2}$ in neutral and acidic media afforded erythro-rich products in a moderate degree, similar to results of sodium borohydride reduction. ${ }^{3)}$ While erythro-rich products were obtained in high stereoselectivity with the addition of sodium hydroxide. On the other hand, catalytic reduction of I with Raney Ni W-2 afforded threo-rich product in low stereoselectivity. Although the results after the equilibrium of the diasteromers ${ }^{4)}$ would seem to be the relevant data, we confirmed that the diastereomeric ratios of the reduction products could not be equilibrated with either $5 \%$ Pd-C ${ }^{3}$ or Raney Ni W-2 in ethanol under the present reduction conditions.

In the catalytic reduction of II, threo-rich products were obtained with $5 \% \mathrm{Pd}-\mathrm{C}$ and $\mathrm{PtO}_{2}$ in ethanol in moderate stereoselectivity.

Results of the reduction of 2-aminopropiophenone hydrochloride (III) and 3-amino-2methylpropiophenone hydrochloride (IV) are shown in Chart 1. Catalytic reduction of these ketones with $5 \% \mathrm{Pd}-\mathrm{C}$ and $\mathrm{PtO}_{2}$ in acidic media was almost completely stereoselective, resulting in a predominantly erythro-isomer for III, threo-isomer for IV. Analyses of diastereomeric ratios in the products using nuclear magnetic resonance (NMR) were impossible, because signals due to the minor diastereomers were not observed in the spectra. Examina-

4) cf. a) R.L. Augustine, “Catalytic Hydrogenation," Marcel Dekker Inc., New York, N.Y., 1965, p. $86 ; b)$ E.L. Eliel and S.H. Schroeter, J. Am. Chem. Soc., 87, 5031 (1965). 
<smiles>CCNC(C)C(=O)CC</smiles>

III

\author{
1) $5 \% \mathrm{Pd}-\mathrm{C}$ or $\mathrm{PtO}_{2}$ \\ in $\mathrm{EtOH}$ or $\mathrm{AcOH}$ \\ 2) $\mathrm{OH}^{-}$
}

(a)<smiles>CCCCC(O)C(C)N</smiles>

erythro-isomer (>95\%)<smiles>CCC(=O)C(C)CN</smiles><smiles>CCCCC(C)O</smiles><smiles>CCCCC(O)C(C)CN</smiles>

threo-isomer (>95\%)

\section{Chart 1}

tions of synthetic samples of known compositions have shown that the $4.4 \%$ existence of a minor diastereomer could be detected in NMR spectra, ${ }^{3)}$ thus, these reductions were effected more than $95 \%$ stereoselectively.

These data show that the direction of 1,2-asymmetric induction in the catalytic reduction of propiophenone derivatives with $\mathrm{Pd}-\mathrm{C}$ and $\mathrm{PtO}_{2}$ in acidic and neutral media is also dependent on neighboring functional groups; giving erythro-rich products in the reduction of ketones having $-\mathrm{NH}_{2} \mathrm{HCl}$ or $-\mathrm{OCH}_{3}$ group at $\alpha$-position to the carbonyl group, but threorich products in the reduction of ketones having this kind of functional group at $\beta$-position to the carbonyl group. Moreover, it may be possible, from the synthetic point of view, to anticipate a high degree of stereoselectivity in the reduction of acyclic $\alpha$-amino ketones and $\beta$-amino ketones with $\mathrm{Pd}-\mathrm{C}$ or $\mathrm{PtO}_{2}$ under acidic conditions.

\section{Experimental ${ }^{5)}$}

Materials- $-5 \%$ Pd-C (dry) was purchased from Nippon Engelhard Co., Ltd., and $\mathrm{PtO}_{2}$ was purchased from Koso Chemical Co., Ltd. Raney Ni W-2 was prepared according to the method in the literature. $\left.{ }^{6}\right)$ The ketones (I-IV) were prepared according to method reported in the preceding paper. ${ }^{3}$ )

General Procedure for Catalytic Reduction—-The catalyst $\left(100 \mathrm{mg}\right.$ for $5 \%$ \%d-C or $\mathrm{PtO}_{2}, 0.2 \mathrm{ml}$ for Raney Ni W-2 (wet)) was mixed with the solvent $(20 \mathrm{ml})$ and the whole was stirred under atmospheric pressure of $\mathrm{H}_{2}$ at $2-15^{\circ}$. After the absorption of $\mathrm{H}_{2}$ ceased, a solution of the ketone ( 3 mmoles) in the same solvent $(10 \mathrm{ml})$ was added and the whole was stirred again under atmospheric pressure of $\mathrm{H}_{2}$ at $2-15^{\circ}$, until absorption of $\mathrm{H}_{2}$ again ceased. The catalyst was filtered off, and washed with a small amount of the same solvent. The combined filtrate and the washings were evaporated in vacuo to dryness. In the reduction of I and II, the residue was subjected directry to analysis of the diastereomeric ratios by gas chromatography ${ }^{3}$ or NMR spectroscopy. ${ }^{3)}$ In the reduction of III and IV, the residue was taken up in $\mathrm{H}_{2} \mathrm{O}(c a .5$ ml), made alkaline by the addition of satd. aq. $\mathrm{K}_{2} \mathrm{CO}_{3}(7 \mathrm{ml})$, and the whole was extracted continuously with ether. The ether solution was dried over anhyd. $\mathrm{Na}_{2} \mathrm{SO}_{4}$ then evaporated to dryness in vacuo to give a residue, which was subjected to analysis of diastereomeric ratio by NMR. $\left.{ }^{3}\right)$

Solvents used in these reductions were $\mathrm{EtOH}, \mathrm{AcOH}, \mathrm{HCl}-\mathrm{EtOH}(15 \mathrm{mmoles}$ of $\mathrm{HCl}$ in $30 \mathrm{ml} \mathrm{of} \mathrm{EtOH})$ or $\mathrm{NaOH}-\mathrm{EtOH}$ (15 mmoles of $\mathrm{NaOH}$ in $30 \mathrm{ml}$ of EtOH).

Examination of the Change in the Ratios of Diastereomers under the Reduction Conditions-a) Reduction of III with $5 \%$ Pd-C: Reduction of III in EtOH was performed as in the general procedure and the ratios of diastereomers produced were analyzed at intervals by gas chromatography. Data on the ratio of erythro: threo and the reaction time (in parentheses) were as follows: $1.9(5 \mathrm{~min}) ; 2.0(10 \mathrm{~min}) ; 2.0$ (20 $\mathrm{min})$; $2.0(30 \mathrm{~min}) ; 2.0(45 \mathrm{~min}) ; 2.0(60 \mathrm{~min})$. In this reduction, the reaction was almost complete after $45 \mathrm{~min}$.

b) With Raney Ni W-2: The reduction product (erythro: threo=1.8) of III in EtOH was subjected to the same catalytic reduction conditions as in the general procedure with Raney Ni W-2. Ratios of the diastereomers were analyzed at intervals by gas chromatography. Up to $300 \mathrm{~min}$, the ratio was found to be unchanged.

5) Gas chromatographic data were obtained with a Shimadzu Gas Chromatograph GC-1B equipped with a hydrogen flame ionization detector and a column of Carbowax 20M. NMR spectra were measured in $\mathrm{AcOH}^{3)}$ with a JNM $3 \mathrm{H}-60$ spectrometer operating at $60 \mathrm{MHz}$ using TMS as an internal standard.

6) R. Mozingo, “Organic Syntheses," Col. Vol. III, ed. by E.C. Horning, John Wiley and Sons, Inc., New York, 1955, p. 181. 